\title{
Martin Luther and the different spirits of capitalism in Europe
}

\author{
Luigino Bruni ${ }^{1} \cdot$ John Milbank ${ }^{2}$
}

Published online: 1 June 2019

(c) Springer-Verlag GmbH Germany, part of Springer Nature 2019

Theology has been for centuries at the centre of the work of thinkers concerned with economic and social matters. From the very beginning of Christianity up to modern Political economy, a cross-fertilisation between theologia and oikonomia has occurred. Smith, Marx, Vico and Genovesi, for example, deployed theological languages and their theoretical systems were influenced by the theological debates. According to Benjamin 1986 [1921], capitalism is a new form of religion that calls for an exclusive form of worship and aims at replacing Jewish-Christian humanism. For this view (that is more consistent with Marx's vision of capitalism, than with Weber's), modernity is not characterized by a disenchantment of the world, but instead by the affirmation of a new credo-that is by the transformation of the Christian spirit into the 'spirit' of capitalism.

This Special Issue argues that theology is very relevant for understanding the differences between Anglo-Saxon (Protestant) and Latin European one (Catholic) capitalisms - the contrast between the economic spirits of the North and of the South of Europe. The Reformation and Counter-Reformation were decisive turning points in the history of Europe, helping to generate a new 'modernity' in economic as well as theological terms. In consequence, the contemporary contrast in economic and social terms between North and South Europe can be seen as the double fruits of an interrupted path. The social pathologies, i.e. the 'amoral familism' and the corruption of 'mediated society' of the Italian and Mediterranean societies are well-known and represent serious feelings. At the same the Protestant individualism is facing a different crisis that is no less grave and perhaps more so, with repercussions everywhere. Both pathologies call for a remedy that would represent something new and perhaps a resumption of our once shared European path.

Luigino Bruni

1.bruni@lumsa.it

John Milbank

john.milbank@nottingham.ac.uk

1 LUMSA University, Rome, Italy

2 University of Nottingham, Nottingham, UK 
Before the Reformation irruption, market economy had emerged and expanded as a distinctively European phenomenon, from Palermo to London, from Lisbon to Prague. Christian faith had represented the new philia (fides: trust) that, as in the polis of Aristotle and Pericles, but now cosmopolitinised, made possible trust and trading among different people belonging to different clans and villages. The scholastic philosophers and theologians-Aquinas in particular-developed an ethics suitable for the new urban-rural international civilization linking trade with agriculture and manufacture, based on the pivotal idea of common good. This involved the thesis that the good of the individual has to be seen in deep and necessary connection with the goods of association and of the community. From that vision derives a conception of an ethical economy-involving requirements for just prices, the severe limitation of usurious lending, the restriction of money to non-commodifiable means, etc-that was ontologically at once communitarian and hierarchical. In the conception, the crucially established mediators (priest, abbot, king, lord, father... but much more often than we think also Abbesses, Ladies and Mothers...) were the basic mechanism to implement the harmonization of public and private goods. Furthermore, in the late Middle Ages the cross-fertilisation (and sometimes contamination) between market and religion had reached a vast expansion: indulgences, poor people paid by the rich ones for making prayers and penitence in their place, donations of bankers for buying reduction of years of purgatory and so forth.

Martin Luther reacted strongly against at least two elements of southern Christianity: (a) the excessive and often insane mixture of money with grace, (b) the magnificence of Rome and Italy that were also the fruit of the wealth created by a new and positive attitude towards luxury and money during the 'Renaissance' period of the Fourteenth and Fifteenth centuries. He was deeply struck and shocked by the mundane and market-based society he met in Italy, which he considered to be far from the original message of austerity and poverty of the gospel.

Thus the strong reaction of Lutheran and later Calvinist Reformation was not only against the theology of the Roman church, but also against the style of living of the Italian Renaissance, its palaces, masterpieces of art, the newly pagan-influenced art of Michelangelo and Leonardo. Therefore, the protestant cultural programme involved also a reestablishment of a more authentic and less money-oriented society.

But, paradoxically, and in part due to the elimination of the hierarchical mediation of the church, the Protestant culture ended up creating an environment much more adapted to the further development of the capitalist economy (Barbieri 2013). In fact, while in southern Europe the Counter-Reformation to a degree qualified and halted the process of freedom in commerce and politics started earlier encouraged by civic humanism, in the northern Protestant countries a further-unleashed individual freedom was the main engine of capitalistic revolution. Thus with a yet further irony, it was in Northern protestant Europe that civic humanism and the Renaissance revolution in arts and letters continued, while in Catholic countries, such as Italy or Spain, the Mannerist and Baroque eras resulted in a certain repristination and even contractual hardening of older 'feudal' structures, which now often tended to partially coopt purely commercial ones. The situation of France can in these respects as in others be regarded as partly medial: just as Gallicanism and State-absolutism echoed strong Protestant state structures, so also a later Jansenism in religion 
encouraged psychological attitudes and social structures not entirely dissimilar to Protestant ones.

The role of mediation by the Catholic Church is a very key point here. Unlike the Protestant world, in the Roman context the church and its institutions played a central role in the legislation upon commerce and money, using a theological vision that remained in fundamental ways Medieval, and often Thomist, to whatever degree certain restrictions, as on usury, were somewhat relaxed in order to compromise with the new secular realities. Whatever the technicalities here, the prevailing cultural spirit, institutionally and theological supported, remained rooted in an older world. Potential civic humanist developments of a town and market economy in a freer but still reciprocally just direction tended to falter in favour of a newly rigidified version of a Medieval order-one that now, ironically in its own way tended more to stress outright ownership, but mainly of fixed terrain, people and privileges.

Thus, the restraint exercised by the institutions of the Catholic church upon individual economic activity, and the strong tools of implementation of this control albeit often further mediated by the state (as in the case of the Spanish Inquisition) left the countries of South Europe (Italy, Spain, Portugal, France to a degree) in a condition of economic and financial disadvantage with respect to Northern Europe, especially in view of the fact that the latter region increasingly set the rules of the game both at home and in the merging overseas empires. Due in part also to a lack of religious hierarchy, in Holland and in the other Protestant countries financial and money lending was permitted an almost unrestricted scope, while outright private property and exactly specified contract were more underwritten by law. Against this background, unrestricted commerce, individual wealth, capital accumulation and financial growth expanded in an unprecedented fashion.

Parallel to this, whereas in the North Europe and later in the USA, thanks to the impact of Calvinist ethics, labour and business were considered to be moral ways of engaging in ordinary life, in Italy of the Baroque period the re-feudalization of the culture involved a new praise for rural life and diffidence towards commerce and the city. It is true that most ecclesiastic, political thinkers, theologians of the post-Counter-Reformation era were lauders of labour: but the labour praised was agricultural and intellectual work, whereas the manual or artisan's activity in the cities (smiths, carpenters, shoemakers, etc.) were considered to be not noble but servile, in contrast with the Renaissance and later Baconian elevation of the dignity of the artisanal of which the higher status of the Renaissance artist had been a part. Most of the present-day differences in labour culture, attitudes to public debt, private and public ethics, in state welfare, individual rights and conceptions of the market lie in the two different ways that Europe took after the Reformation and Counter-Reformation eras.

\section{Capitalism and Catholicism}

At the time that the Protestant Reformation was still intensifying in Norther Europe, despite very significant geographical setbacks (France, Poland), and the Puritan pilgrims were occupying the new 'promised land' in North America. The ideas and 
doctrines of Jansenism were already breeding in the Netherlands and in France. But at the very same time the Counter-Reformation, the doctrine and practice of the Jesuits, and the action of the Holy Office were gathering momentum across Italy, Spain, and Portugal. It is from this contradictory double development that civil economy will be born in the eighteenth century.

Even before Martin Luther, a notable difference had existed between Latin Catholic Humanism and the spirit of north Europe. Prior to the Christian saints, the Italians had worshipped their household gods (the penates) and other Roman deities and held processions in their temples. Roman Christianity transfigured the social culture they had created; but it found space within it in which it could grow and take a mediated form. This syncretic culture included from ancient times its own mode of urban and commercial life. Below the Alps therefore, the market already existed before the diffusion of the Calvinist spirit and to this day it continues to exist with own distinctive character.

In medieval times the accumulation of wealth drew such strong opposition that greed was labelled a capital vice; people were taught to cultivate an ethics of selfcontentment and not to envy those above them. The Gospels and the message of Christ were unambiguous about money and wealth; and the economic ethic of the first millennium AD, as shaped first and foremost by the Early Church Fathers, contained a strong critique of money and of the pursuit of wealth in which the attainment of true wealth was deferred to the heavens. Even the notion of private property, while sanctioned as a legitimate individual right, was «much tempered and closely bound up with the rules as to the social use of property» (Fanfani [1934] 1935, p. 126).

The development of early trade practices and the foundation of the Franciscan and Dominican orders favoured the shift to a more open view of trading activity and investment and even of money lending, even if most Franciscan thinkers moved much further towards individualism and away from notions of the common good than did the Dominicans' activity (think for instance of Peter John Olivi, Scotus and Occam). Nonetheless Christian ethics did not evolve into a fully-fledged capitalistic ethic; nor did it encourage the accumulation of wealth in the 'valley of tears' for its own sake: «Wealth is thus a gift of God, and therefore not to be condemned. But men must not seek it so eagerly as to forget to lay up treasure in heaven, and they must walk carefully» (Fanfani Ibid., p. 127). From the first centuries of the Christian era, wealth is sublimated into a means and a sign: «The most striking aspect for someone trying to comprehend the social views inherent in early Christianity is the radical transformation and broadening of the idea of wealth from a means to satisfy earthly needs and pleasures into a nobler path to the heavens». The framework established by the Church Fathers, which went on to be a major influence in medieval culture and was itself informed by the Greeks, by Seneca, Cicero and the Romans, hinges on the notion of need: wealth that is not meant for, or exceeds, the satisfaction of needs is illicit: «His [of the miser] horse, his land, his servant, his gold is worth 15 talents; he is worth 3 soldi» (quoted in Barbieri 2013, p. 118). ${ }^{1}$

\footnotetext{
1 From the Book of Proverbs to Aquinas, the figure of the 'ant' is famously praised for working hard and gathering resources instead of spending them. In addition, the general mistrust of the market and com-
} 
It is not incorrect to say that 'Christian and capitalistic virtues correspond in name but not in signification [...]. Certainly no one can deny that such men as the Bardi, Pitti, Datini, acted in a capitalistic manner, and, though baptized Christians, introduced a capitalistic mode of life among their Catholic contemporaries. But we deny that in so doing they were acting in conformity with Catholic social ethics. [...] Only unawares can Catholics truly conforming to their faith have favoured the development of capitalism - as understood in the sense we have already many times defined. Or else, only by consequences that humanly and practically could not be foreseen, could certain actions on the part of real and true Catholics have favoured capitalism' (Fanfani [1934] 1935, pp. 151-154).

Yet it was exactly this brand of anti-wealth and anti-capitalist Christian spirit that during the second millennium that nonetheless apparently allowed Florence, Venice, Paris, Lisbon, and London to thrive with wealth and usurers, as well as Rome with its boundless luxury. Fanfani then raises another interesting point: «This fact makes us ask ourselves if it be indeed true that Catholicism always opposed the capitalistic spirit as it revealed itself in a Catholic age» (p. 170). And: «If Catholicism and Catholics did not pave the way for the advent of capitalism, when and where did this come about? In Protestant countries after Luther's revolt? Many declare that it flourished in such countries, but as for its birth, no one now denies that it took place before the Reformation, and hence in Catholic countries, among Catholics» (Fanfani, Ib. p. 160). His answer is that the capitalist spirit emerged prior to the Reformation out of certain 'deviations' from the Catholic ethic as a reaction to a new set of circumstances affecting Europe between the fifteenth and sixteenth century. The merchant began to benefit from a set of exemptions unavailable to other social actors: «In medieval economic society the only individual who could easily and often find himself in a position to act otherwise than in conformity with precapitalist economic ideals was the merchant» (p. 177). ${ }^{2}$

This shows the prevailing opinion of the morality of commerce and of the markets in the Middle Ages. Suspicion and caution towards merchants and their activity remained ingrained within the Southern European Humanism, whereas, after the Reformation and through the Calvinist equivalence of wealth as blessing, the pursuit of profit has been turned from vice into the highest virtue of the capitalistic ethic - a transformation that has come to affect all forms of life on our planet. However, the main point in Fanfani's argument is that the real conflict behind the Reformation was not theological, but civil: a clash between the Germanic world, organized around an archaic and feudal order, and Italian and Latin Humanism: «As it came into contact with the Latin world imbued with a new humanistic vocation and exhibiting the soft traits of the Renaissance, the Germanic world retreated in horror. Luther thought ill

Footnote 1 (continued)

merce was fed by the antipathy towards merchants, who were seen in Christianity as parasites who create no value and earn their living from speculation.

2 Among such 'deviations' or 'transgressions' the most striking occurred in the sphere of long-distance international commerce and in response to a substantial increase in the risks (which legitimated otherwise inadmissible profits). In such situations merchants were able to act outside the moral control of their cities. 
of the nature of this renewed spirit and responded» (Fanfani 1968, p. 508). Hence: «The Reformation, which in him found its beginning and its energy, was first and foremost a protest, and only afterward a restoration. [...] That world that revolved around man, in which others-objects, time, mind, pray-were aimed at enhancing the individual enjoyment of life was seen as heresy in the eyes of his/its first followers» (ibid.). This argument is not dissimilar from Max Weber's: «And what the reformers complained of in those areas of high economic development was not too much supervision of life on the part of the Church, but too little» (Weber 1976 [1905], p. 5).

Luther's protest, even more than Calvin's, mostly targeted the Roman and Italian Humanism and Renaissance and not exclusively their theological deviations (like the indulgences) or the corruption of the clergy. It was, all in all, an anti-humanistic and anti-Renaissance critique that extended to the Counter-Reformation: «The Latin world reacted to the Protestant critique, but its reaction was primarily ecclesiastical. Thus came the Counter-Reformation that, sharing into the original criticism of Protestantism to the ideals of Humanism and of the Renaissance, detached the latter from its own and made it so that men, without forgetting the arts, the letters, and the discoveries that had been perfected with Humanism and the Renaissance, could use them to live a life lightened by Christian values» (Fanfani 1968, p. 509). Therefore, according again to Fanfani: 'Humanism-Renaissance and Protestantism walked the same path, they were two moments of a single revelation that man gave to himself: the "naturalistic" revelation' (Ibid.).

\section{Economics of the Counter-Reformation}

When the Counter-Reformation set out to restore the Middle Ages, the Protestant Reformation took on the attitude of increasing amenability to commerce and to modern attitudes that had, ironically, originated in Humanism and the Renaissance. But the restrictive Catholic framework and mediating practice that had embedded the economic in the social, prevented the total subordination of Capital to Labour, and sustained the overarching framework of the common good was increasingly abandoned.

In the Northern countries, the view of individualism endorsed by the Reformation laid the groundwork for the production and creation of wealth. In the Catholic countries by contrast as we have seen the Counter-Reformation tended not only to refuse Protestant successes, but also in reaction to reject the civic humanist legacy and instead to adopt an ironically modern because more fixed and contractualised version of feudalism-whereas older Medieval 'feudalism' had been much more of a looser type of hierarchised gift-exchange. Static modes of ownership divorced from personal responsibility were now much more common. Where once property, however unequal had been rooted in personhood, now it was the other way round, even though property in the south was less exchangeable and more linked to unalterable inherited status. In so doing it encouraged an ostentatious type of consumption based on positional goods, as well as the pursuit of 
revenues, land ownership, and property holdings; at the same time, it discouraged economic activity, crafts, commerce, and private initiative.

The reaction of the Catholic Church against the values of the Reformation thus also led to a re-evaluation of the values of Humanism and Renaissance and, ultimately, to the end of the fledgling market economy that European Humanism had been building in a spirit of genuine freedom. The Northern cities then gave rise to a capitalism of their own, just as the Southern cities saw the perverse reworking of an older, rural order enforced by newly established institutions, like the High Office and the Inquisition. The same amount of effort poured by these institutions into the fight against heresy and the ensuring of cultural conformity was devoted in the North to the creation of companies and banks.

In other words, the Counter-Reformation brought to a halt the non-capitalist market economy that emerged in the Middle Ages and evolved into Civil Humanism, which was simultaneously personalistic and communal, capable of reconciling individual freedom and the common good with the fundamental role of the great charismata, the teachings of medieval theology, and the primacy of free civic institutions in the Italian city-states. By eliminating the Church mediation and control from the citizens' daily lives, Protestantism established a climate of personal freedom that favoured the development of modern capitalism as a continuation of the European market economy of the thirteenth and fourteenth century: a continuation predicated on new terms.

All this was much reinforced by Protestant theology: even though it revived traditional Catholic disapprovals of greed and ostentation in the face of some Renaissance manifestations, its very despair in the face of corruption led it to embrace doctrines of total depravity which left ethical and social reform somewhat futile. In consequence of this, the role of the Church as a more ideal community rather than the guardian of individual souls is somewhat abandonedthough far more by Lutheranism than Calvinism. Concomitantly, the regulation of affairs becomes relatively amoral and pragmatic. For this double reason, the ending of ecclesial mediation in the market is reinforced: given the death of a reforming optimism with respect to human conduct in general and economic conduct in particular, it has no remaining point. Thus, supposedly hypocritical ostentation is refused, but a more measured economic pragmatism is unleashed. In time, and supremely in the case of the USA, this will eventually and ironically unleash an unprecedentedly vulgar mode of ostentation and tasteless luxury. This is the schizophrenia inherent to the modern 'northern spirit'.

We cannot begin to comprehend the eighteenth century and the major antifeudal shift that took place in Southern Europe, where a reconsidered Providence became central to the view of the market and commerce, if we do not consider the special context of Catholic Europe. After the sixteenth century and for the following two or three hundred years, the path to the 'civil' market seemed lost. The civil and commercial virtues of Siena, Florence, Venice, Barcelona, and Lisbon were replaced by the desire for land and revenues. A renewed Civil Economy was what was needed. If this did not happen right away, it is because the economic impact of the Counter-Reformation was not immediately perceived. It was not until the second half of the sixteenth, and into the seventeenth century, that its 
characteristic traits became manifest, in terms of 're-feudalization' and the return to the land.

A concern to resist this and even in terms that were now specifically modern and capitalist, were nonetheless apparent from quite early on within the south. In the very same years Luther was carrying out his Reformation, Cardinal Cajetano in his commentary of Aquinas' Summa affirmed the ethical legitimacy of seeking wealth beyond the conservation of one's individual social and economic status within the hierarchy (Barbieri 2013) in a manner that went arguably somewhat beyond Aquinas-although this may be a matter of interpretation.. came closer, instead, to the positions of Franciscan Bernardino of Siena (first half of the fifteenth century), the Dominican Bishop Antoninus of Florence (latter part of the century), or lay humanists Leon Battista Alberti, Coluccio Salutati, and Poggio Bracciolini, who were among the main interpreters of Civil Humanism.

During the Reformation, moral philosophers like Cajetan and Garimberto concentrated their hermeneutical efforts on finding arguments to legitimate interest-bearing loans.. Among such arguments were the distinctions between lucrum cessans (ceasing profit, not allowed by Aquinas and damnum emergens (allowed by Aquinas)), and between usura (excessive interest rate resulting from monetary speculation) and fair interest (equo) on loans towards complex and risky trade ventures. Within Civil Humanism and during the Renaissance such analytic distinctions had made it easier for trade and economic activity to gain acceptance by the Church compared to earlier (and later) centuries. However, one should not here a certain drift towards capitalist norms under these Franciscan auspices, which had begun questionably to regard money as a 'thing' and to think that a private pursuit of private gain with no direct reference to the common good might be valid. To a degree and alternatively civil economy transpired still within the apparently more rigid terms of Aquinas's economic thought. This apparent rigidity sill that nonetheless permitted monetary loans if they were bent in the direction of risk-shouldering investment. Given the financial chaos of today, we cannot so lightly dismiss the Angelic doctor's wisdom in this respect. The writings of the Jesuit preachers (among others) appeared between the sixteenth and seventeenth centuries show that the Counter-Reformation, however, reveal a reaction against Cajetan-style modifications. The leaders of the Counter-Reformation-Castiglione, Bartolomeo of Salutio, Gattioli, Segneri, etc.deemed guilty of a 'mortal sin' (peccatum mortale) those «not content with their condition and status» (Castiglione, quoted in Barbieri 2013, p. 12).

We would, however, not acknowledge correctly the main reasons for the renewed condemnation of usury and interest rate unless taking seriously the rent-seeking nature of financial activity. Actually, if we go back to the Bible, we find that the main component of the condemnation of interest upon monetary loans was a radical critique of the 'rent' of the interest rate, which amounts to a criticism of making money when not real risk has been borne and not value-added labour has been performed. To make money through mere possession of a scarce resource, money, that is moreover just an instrument of trading good and not a good in itself was considered as a disease of the social body - as all form of pure sent-seeking isGiuseppe Toniolo, the main catholic economist between XIX and XX century in Italy, criticized the usury exactly on this basis. All this points precisely towards the 
essential validity of the Thomistic demand (which the Franciscan position betrays) that interests on loans be re-interpreted as legitimate shares in the enterprise that the borrowed money has been invested in. Of course this point of view (close to that of Islamic economic teaching) accords the money-lender certain new participatory rights in compensation for the removal of irresponsible and unjustified ones.

Nonetheless, the motivations of the Counter-Reformation theologians did not lie in the direction of reviving an ethically valid civil economy, but of upholding a much more moribund rural order.

\section{The architectonic and the naturalistic: one more difference between North and South}

The Humanist Renaissance and the Protestant Reformation constituted two reforms of the medieval spirit, two different transitions from an 'architectonic' (that Fanfani, in line with the Franciscan/Scotus tradition called 'voluntarist') or 'directly intentional' outlook (for which human beings are ambivalent and it falls on the institutions, and hence on the hierarchy, to steer them towards their better inclinations) to 'naturalism' (i.e. natural interests and passions are naturally good though morally neutral or even evil but can be naturally and automatically balanced by each other). In fact, the medieval (and Greek-Roman) world is based on the Aristotelian architectonic assumption, which gives primacy to politics. In the modern world, on the contrary, naturalism has prevailed (initially with theological support) and primacy has shifted to economics, thereby eliminating the need for mediation: 'Finally the politician has been deposed. He is no longer the regulator of human existence [...]. Having discovered the immanence of the rational order, his exertion has been rendered superfluous and even harmful. His mission is to live at the margins of the economy and of the crumbs the latter reluctantly accords him. The relations set up by modern voluntarists between economics and politics have been turned upside-down. And even politics has been exonerated from the task of maintaining economics on the plane of morality. Freely competing egoisms deliver this prodigious result, too, of giving rise to an order that not only fares better economically, but is even more just and better' (Fanfani 1942, p. 176).

Classic voluntarism begins with the idea that the human being is ill with selfishness, but remains a social animal capable of relationality. This notion was rooted in the Bible and was later grafted onto the Greek world (where it can be found in Aristotle and, differently stated, in Plato and in Stoicism). In St Thomas's remarkable synthesis we find an acknowledgment, and reassertion, of this biblical root as well as of the need for institutions and social rules to prevent such fragile nature from falling 'ill' (on this point see Aristotle's view of chrematistics, which remained virtually unchanged in St. Thomas and throughout the Middle Ages).

In this anthropological perspective man is seen as an ambivalent being equally capable of virtue and of vice: 'A positive and optimistic view of human nature became prevalent after Thomas Aquinas: in spite of the original sin, humankind has preserved the ability to discern good from evil and the impulse to choose good and regret evil' (Prosperi 2017, p. 74). Erasmus of Rotterdam, one of 
modern Europe's most fundamental figures (whom Luther in fact accused of NeoPelagianism in his private letters), held the same positive view.

Institutions thus had the crucial and twofold task of enabling man's virtuoussocial soul to find expression, while restraining his 'vicious' side. In human beings virtue is a natural and co-essential trait. The main message of virtue ethics, as we'll see shortly, is imbued = with anthropological realism: man is at the same time angel and beast (Pascal), agape and egoism. In order to strengthen virtue, we then need to foster education, schooling, rewards, and institutions. It is at this point that the architectonic comes in: common good must be institutionally constructed, not just accepted as the indirect and unintended product of competing but inter-balanced vices. A critical element in such Humanism is the mediating role of the institutions, which are here 'communal' and relational (rather than automatic and anonymous).

In this respect too, the Reformation was an epoch-making shift. The anthropological approach at work in Protestantism, steeped as it was in Luther's unprecedented pessimism, no longer depicts human beings as truly capable of positive reciprocity in relation either to Man or to God.. In this perspective the direct cooperation of men and women ought to be discouraged since it will always be covertly a demonic masquerade and the common good (still a major theme) ought to be reconstrued in terms of a rule-observing game played out between isolated interests.

In the architectonic and more directly intentional view widely held within Catholic Humanism, the economic order is not a spontaneous order.

And in line with its Catholic cultural origin, Civil Economy - and generally the Latin and Italian economic and political tradition-has maintained this directly intentional approach, which ascribes a fundamental role to the mediation of institutions and of the State (whether in the case of the of mixed economy, a state and legally-established economic framework or a mutualist economic culture)). In fact, this was the case up until recently, when a naturalist-based paradigm has with the onset of neoliberalism, become uniquely prevalent across much of the world. Medieval 'architectonic' theories then should not be seen as overlooking the 'true' nature of the market, understood as the intertwining of mutually advantageous relationships or as a 'positive-sum game' (an insight held by several of these authors); nor do these older theories fail to acknowledge the incentivizing nature of interests and profits. Rather, the architectonic vision is the expression of a view of man and society in which the good of all and of each does not arise from the sum of interests, but from the encounter and interaction of virtues: «They remark [quoting Montcrétien and Botero]... that man operates in view of utility [...]. They value the importance of such a force in that it animates economic life [...]. Notwithstanding, they refuse to believe that the free action of individuals moved by this very instinct may actually lead to social well-being» (Fanfani 1942, p. 167).

It is no surprise, then, that Fanfani should quote Antonio Genovesi and acknowledge the importance of his Lezioni di economia civile. After mentioning the Neapolitan abbot's book, he remarks: 'Liberty without rules always has pernicious effects on people and on civil societies. On people because it ushers them to the excesses of passions; and on societies because, by leading men solely to their personal or domestic interest, it corrupts the public good in countless ways...because the profit 
of the merchant should not be confused with the profit of the State. It may well leave the merchant rich and the State ruined' (Ibid., p. 167).

At the height of the Middle Ages, Southern Europe with its long history and wide biodiversity gave rise to a market economy informed by the Catholic paradigm which was, therefore, the expression of a community-based and institutionally 'mediated' idea of society. In the north, Protestantism produced the idea of a society of individuals rid of the intermediate institutions, as visible both in the case of the politically economic 'invisible hand' and the political Leviathan or Panopticon of Bentham (China today!) which must police the interactions of individuals with an absolute authority. In the space of freedom of the State, Market established by the social contract, common good is not left to the mediation of institutions; it is the unintentional outcome of the action of separate and independent individuals. Both economism and statism result from this. They can be contrasted not just with the moribund order of the Latin Baroque, but also with the 'different economy' of the civic humanist tradition of the South.

The main purpose of the several papers of this Special Issue on Martin Luther and Modern Economics and Social Sciences is then to contribute to reconsider the role of the theological element in the understanding the different spirits of the economy generated by the Modern Christian Europe.

\section{References}

Barbieri G (2013) Decline and economic ideals in Italy in the early modern age. Leo S. Olschki Editore, Florence

Benjamin W (1986) Capitalism and religion. In: Liedemann R, Schweppenhäuser H (eds) Gesammelte Schriften, vol 6. Frankfurt, Suhrkamp, pp 100-103

Fanfani A (1935) Catholicism, protestantism, capitalism. Sheed and Ward, London

Fanfani A (1942) Il volontarismo [Voluntarism], Como

Fanfani A (1968) Storia economica, vol. I: Antichità, Medioevo, età moderna, Turin

Prosperi A (2017) Lutero. Mondadori, Milan

Weber M (1976) [1905] The protestant ethic and the spirit of capitalism, translated by Parsons T. London

Publisher's Note Springer Nature remains neutral with regard to jurisdictional claims in published maps and institutional affiliations. 